\title{
CLIMATE CHANGE AND CORPORATIZATION OF FOOD
}

\author{
Mohammad Mohnish \\ Research Scholar, MMIJ Academy of International Studies \\ Jamia Millia Islamia, New Dellhi, India \\ Email:mohnish.raul@gmail.com
}

\begin{abstract}
Climate change together with social injustice is the important factor which impacts large population globally. The effect is experienced both on health and social life of an individual. Developing economies require governments to allow Foreign Direct Investment, which paves the way for Multi-National Corporations to acquire control over resources. This control of resources is acquired by promises to tackle the issues of food insecurity. Climate change has metamorphosed into a boon for MNCs in food sector. It has altered the crop pattern and increased the dependency of farmers on genetically modified seeds. This paper intends to establish how the concept of climate change has become a boon for MNCs in food sector. Companies like Monsanto, DuPont, sell the idea of genetic engineering to solve the problem of food scarcity by boosting crop yields. This paper argues that increasing the amount of food through genetically modified technology does not necessarily lead to food security.
\end{abstract}

Key words: Climate Change, Food security, Biotechnology, MNCs and Social Injustice

\section{Introduction}

Climate is a precarious decisive component for food security but with the progress of science, advanced steps have been taken to control the forces of nature. Science has generated the ability to manipulate the resources and control the environment according to the needs of humanity. The only requirement is the justification of economic returns. The plausible returns allow creating man-made microclimates, strain plants and animals together with considered necessary characteristic. Climate change variables also impact biophysical aspects like animal and plant growth, biodiversity, water cycles, and nutrient cycling. These impacts lead to indirect alteration of the financial and socio-political aspects that regulate food availability and consumption. While technological innovation is seen as a way to relieve the world of the problems of food insecurity. This paper seeks to highlight the problems associated with this argument. While abundance of food through technological advancement has been used as a reason to allow the genetic modification of food, this paper highlights the grave concerns that corporatization of food is bringing to the world. Companies like Monsanto, DuPont, Novartis, and other chemical-cum biotechnology companies sell the idea of genetic engineering to solve the problem of food scarcity by boosting crop yields. The technologies have dubious benefits and well documented risks. Yet these corporations further their agendas by appropriating the ideas of food insecurity. This work rejects the concept of food security as an answer to food problems of the world and argues for the concept of 'food sovereignty'.

Facts designate that more recurrent and more intense weather events, going up sea levels and snowballing abnormalities in periodic precipitation patterns (together with flooding) are now leading direct bearings on food production. It is also affecting food distribution, source of revenue, human health and infrastructure in both urban and rural 
areas. Food security which encompasses the aspects of food obtainability, food availability, food consumption and food system steadfastness have serious impacts due to the change in climatic condition. It is understood that clouts are now being experienced in international food market place and remain predominant in particular rural sites wherever yields be unsuccessful and harvests are declining. Effects are felt together in urban and rural places. The source cycle happens to be interrupted, prices in markets are snowballing, assets and source of revenue prospects are exhausted, power to purchase goes down, human health is compromised, and people who are affected are not capable to deal with it. Two ways in which crop growing is significant for food security are: One the issue of food harvesting that is used by people for consumption; and importantly, makes it available as a means of support for 36 percent of the global collective labor force. In the critically severely inhabited regions of Pacific and Asia, this segment arrays as of 40 to 50 percent, and in sub-Saharan Africa, two-thirds of the operational inhabitants even now make their source of revenue from cultivation (ILO, 2007). In developing countries where people generally have low income and are highly depended on agriculture any distress caused by climate change will have negative impact on livelihood. The rural poor will be laid at jeopardy and their susceptibility to food insecurity will increase.

\section{Probable Bearings of Climate Change on Food Accessibility}

Food production and additional agrarian produces perhaps will rise with collective need, but then again problem is projected of major alterations in agricultural practices and cropping patterns at local level. There has been an abundant deal of exploration on the consequences of climate change on agrarian produce, mainly cultivated crops. Approximately in total 50 percent of farm produce comes from forest and highland ecological unit, collectively with all tree produces, even harvest grown on wide open, arable level terrain account for only 13 percent of yearly international harvest produce. Dry land ecological unit accounts near about 25 percent of crop produce which is both irrigated and rain fed. Coastal ecosystem having about 12 percent of total rice production (Millennium Ecosystem Assessment, 2005).

The assessment of climate change bearings on agrarian produce, earning based on mode of agriculture and supply of food be required to take into account properties of agrarian system. Importantly where climate made biochemical processes are taking place there is a need to understand to what degree, the availability of food will be impacted. A comprehensive understanding of the data of food insecurity further than critical stage discloses that hunger is at surplus 17.2 percent or 1.3 billion people at moderate suffer from food insecurity. This 1.3 billion people fall into the category, who did not receive or could obtain required nutritious food which could be considered sufficient. Further element of risk factor like poor health and malnourishment also increased.

\section{Probable Bearings of Climate Change on Food Consumption}

Insecurity in food consumption is by and large connected with undernourishment, as people are not able to fulfill their daily requirement of food consumption. Reason for incapacity to nourish oneself can be on the obtainability or insufficiency of food. The decline in nutritional value due to climate change leads to the adverse effect on people's ability to perform daily basis task at its optimal efficiency. Change in climate also effects the life cycle of pest in turn set off new variety of disease and pest. These new perils add to the challenge of already existing food security further becoming hazardous to both plants and human health. Flood prone zones face increasing manifestation of water borne diseases. The new pest or vector originates which is climatic receptive. Initially the new change in cycle is out of the grasp of humans. By the time the adaptive nature of pest and diseases is understood, its impact is already severe on the crops. The crop loses its nutritional value and has direct effect on human health after consumption of food. Any detrition on human health increases the burden on care givers within household, usually its women in developing countries who have to face this extra burden. Due to climate change Malaria is one disease in particular which is expected to alter its dissemination. With rise in sea level, coastal area is 
experiencing flood like situation which further leads to exposure of vector- and water-borne diseases. Change in precipitation pattern can also be linked with change in diseases. Health risks is increased as people's capability to utilize food decreases as proper nutritional intake is absent (IPCC, 2007).3

\section{Effect of Multi-National Corporations}

With globalization, Multinational Corporations (MNCs) have increased rapidly. This acceleration can be tracked to last decade or so. The number of mergers and procurements that have taken place globally is high. Multinational entrepreneurial attentiveness has viable lead, there are sequences of risk associated due to their colossal size and power. One such risk which follows from these enterprises is the new environment where they operate. This new environment possesses the challenges which are in form of mainly legal and cultural. (Lozano and Boni, 2002). The reason MNCs are so competent at directing production in the global structure is the international structure which has made MNCs really adaptive and profit oriented. (Perlmutter, 1972). These features are why supremacy is changing from countries to market bodies (Kobrin, 1998). Regardless of the reality that large corporations are self-regulating performers, operative in the disparities of state-tostate affairs, the concept that home states' uses MNCs as tool in their foreign policy and diplomacy becomes much clearer. (Walters 1972).

Maximum host countries look forward to foreign direct investment (FDI) from MNCs. FDI is an important prospect for incorporating their economies into the international arena and endorsing their financial growth. These nations find that FDI promotes development through a range of methods, such as of providing added health coverage more than the domestic establishments to growing research and development in their own native countries (Erdilek 2003). For several emerging economies FDI acts as a protagonist in growth, and incorporating the country`s market into the international market. Multinational companies' influence has increased with global capitalization and shifting base from place to place around the world without respecting geographical boundaries and they have accomplishments in developing countries owed to appropriate conditions for their growth. Globalization should be considered last stride of economic dominance system by instrument of MNCs throughout the globe by private enterprise which is sensed in this modern stage of development intensely. Boundless investment frameworks of capitalistic society and its purpose for economic progress fastens the complications globally. As an outcome there is no spotting of social developments and justice. As end result of this profit making philosophy, we are experiencing environmental complications and the swiftness of environment's exploitation has been augmented. Though interestingly there exist no admission of the accountabilities of loss and societal strategies in the transnational markets. The global capitalistic economies and multinationals lay down the guidelines as there is no accountability for environmental pollution or natural ownership damage which is an outcome of their environment polluting deeds. The argument or the understanding reason for this is that it's the duty of home government to safeguard and to improve the ecosystem. Bestowing to this impression, protecting and advancing the surroundings have been providing open use for public and community facility. Therefore, civic convenience is the obligation of the government.

Multinational Corporations and Environmentally Friendly Privileges: The War Within Environmental rights theme, acknowledged as rights of third generation, is to safeguard the nature and to foster it. Those who have this privilege of ecological rights are those who have obligation to these rights and should also be one to bring about its use. The inhabitants who practice these privilege and who carry the accountabilities of these rights are usually the same people. These group of people not only comprises people but also general public and distinctive organizations comprising group of people and states. In this set of circumstances, all the right holders who possess the rights to exist in a nourishing and well poised natural world are obligated to safeguard and renovate the ecological system at the same time, counting the large corporations. Each single economic endeavor 
has a consequence on the natural surroundings. The actions of Multinational corporations are basically based in the important sectors like petro-chemical, coal, gold mining and industry like food. Any business related to these sectors does leave an impact on environment all around the globe especially in the developing world. So it becomes important to understand why MNCs choose these countries to invest. We need to concentrate on two reasons for answering this question. Firstly, it is about the laws which exist in developing countries which are very flexible and can be molded time to time with new requirements. Secondly it is all about the people who are not much aware about the consequences to happen on their natural surroundings. If the initial ruling hadn't been correct, the events in principally infesting zones wouldn't have been bound for to the nations where I laws in environment are elastic. Also, the public basic understanding in these less informative countries does not have adequate information in this area of environment issues and significance of natural system. There has been considerable development in this regard and much more awareness has been created in recent times. If local people of host countries find MNCs polluting or degrading the environment, then they are ready to take the challenge and stand up against it. Standing against the giant MNCs may not go well with the government but then it becomes necessary to take such steps. Then again these countries are caught in vicious circle of paying their debts so to this burden to pay back not much devotion is paid to the environmental flaws of the actions and allow the large alien corporations to resume their business in local environment. Consequently, multinational companies are ineffective in partaking environmental accountability in the emerging countries (Akyildiz, 2006).

\section{The Concern with the Industrialisation of Agriculture}

What we all have always learned is that agriculture sector and business houses have by tradition been considered as two distinct zones, both in relationship of their features and their part in economic progression. Agriculture has remained the trademark of the principal platform of progression which acts as a feeder even though the mark of industrial development has been accepted to be the utmost significant pointer of a nation's advancement along the development course. Besides, the appropriate approach for evolution has habitually been perceived as essentially slow but sure transference from farming to industry, through the burden on crop growing to fund the alteration in the first phase. But now new trend has emerged as agriculture sector has become itself an industrial sector where huge MNCs have penetrated their tentacles to reap any profit, even stake is high as depriving future generation of theirs right to food. This has supposed that the utilization of funds in agricultural sector has turn out to be progressively receptive to market potencies and more and more incorporated in the system of industrialized interdependencies.

On the other hand, it is turning out to be all the more challenging to postulate a clear-cut distinction of what is supposed to be deemed an agro-industrial action. The bearing of modernization choices and novel knowhow puts forward a broadening choice of agro-industry inputs that may perhaps be contemplated, together with biotechnological and synthetic produces, for case in point. This infers that agro based industry at present persists to process green agrarian goods despite the fact that it similarly is altering vastly hi-tech mechanized inputs. They regularly provide an outcome of sizable means in research, machinery and invention. The usage of the new modus operandi, comprising genetic engineering is questionable. It has been criticized immensely for its contentious methodology owing to deficiency of facts and data of the hazards involved. It envisions putting forward advanced products, procedures and provisions through wide-ranging agrarian and industrialized quarters. The promoters of these practices foresee that the developing nations will gain substantial benefits as this portion of the globe experiences high scarceness and starvation. What is predicted is not merely food shortage but also major ecological concerns. The skeptical experts to this innovation expresses the substantial socioeconomic consequences and shortcomings biotechnology may well bring about particularly for the deprived segments of the populace. 


\section{Monsanto: A Ruthless Exploitation in Developing Countries}

MNCs impact on environment is immense. All the resources are extracted and further more environment is polluted by MNCs all over the world. One major sector which is facing the wrath of MNCs is agricultural sector. Where MNC like Monsanto have put their foot hold in controlling everything. Monsanto today operating nearly every part of world is the biggest producers of GM crops. It has been advocating GM crops for fighting hunger all over the world. Monsanto claims that its GMOs can reduce world hunger. This daring claim is much to the contradiction of the non-profit union of concerned scientist who says that GM crops are unsustainable and poor countries cannot afford Monsanto products. The seed control by Monsanto over India and across the world becomes cause of concern. It is under the idea of advancing technology where Monsanto tries to hide its real motive of controlling the seeds through patents and intellectual rights. Seed is the source of life which makes it the first link in the food chain. By any means one has control over seed then simply the chain is controlled by that entity. In this case that entity is Monsanto who control life, particularly that the life of farmers.

\section{Conclusion}

The claim by Monsanto sounds absurd when it says that with its GMO crops is way to fighting world hunger. To end hunger, we must transform the food system. Changing the world food system is hauling the whole process and starting the new one. This has a direct impact on how we produce and how consumption takes place. Most importantly, the decision making process is impacted. It causes the balance of power to shift leading to alteration at mass level. This new shift in paradigm is already taking place as decision over food is being made i.e. how food needs to be produced, where to be produced, how distribution has to take place and how does it reach the majority of the masses. Food sovereignty talks about bringing a change which promotes economic and social change together. It deprives business oriented corporations of their motive of controlling the food supply. Importantly it shifts power back into the people's hand, this structural change is created. Local farmers have the rights to take decision over the agricultural activities rather from the people sitting in the board rooms of multinational corporations. The question that arises now is how much governments are willing around the world to take such steps which may disappoint large corporations who brings huge amount of FDI into the host countries. If governments show such will then food sovereignty can be established and at the same time war against hunger can also be fought hand in hand (Holt-Giménez, 2009). Corporations like Monsanto have to put their hand up in making the world better place to live. They may argue the advancement they are making in biotechnology is for the world. But they cannot ignore the implications of the usage of this advancement. They cannot control research in genetically engineering of a plant and publish positive result about it. What is essential is to understand the places where they invest, the kind of cultural society it is. What impact will it have on the lives of people of that region and will they be able to adapt to crafted policies of these corporations.

\section{References}

1. Akyildiz, F., (2006). The failure of multinational companies in developing countries in sharing environmental responsibilities: The case of Turkey. Social Responsibility Journal, 2(2), pp.142150.

2. Alam, G., (1996). Biotechnology, agriculture and developing countries. Economic and Political Weekly, pp.703-704.

3. Bergsten, C.F., (1973). The Multinational Firm: Bane or Boon? Discussion. Journal of Finance, 28(2), pp.457-462.

4. Carpenter, S.R., Mooney, H.A., Agard, J., Capistrano, D., DeFries, R.S., Díaz, S., Dietz, T., Duraiappah, A.K., Oteng-Yeboah, A., Pereira, H.M. and Perrings, C., (2009). Science for managing ecosystem services: Beyond the Millennium Ecosystem Assessment. Proceedings of the National Academy of Sciences, 106(5), pp.1305-1312.IPC

5. Christmann, P., (2004). Multinational companies and the natural environment: Determinants of global environmental policy. Academy of Management Journal, 47(5), pp.747-760. 
6. DaSilva, E.J., Baydoun, E. and Badran, A., (2002). Biotechnology and the developing world. Electronic Journal of Biotechnology, 5(1), pp.1-2.

7. Erdilek, A., (2003). A comparative analysis of inward and outward FDI in Turkey. Transnational corporations, 12(3), pp.79-106.

8. Fao.org. (2020). Climate Change Food and Agriculture Organization of the United Nations. [online] Available at: <http://www.fao.org/climate-change/en/> [Accessed 9 February 2020].

9. Fao.org. (2020). FAO - News Article: World Hunger Is Still Not Going Down After Three Years and Obesity Is Still Growing - UN Report. [online] Available at: $<\mathrm{http}: / /$ www.fao.org/news/story/en/item/1200484/icode/> [Accessed 24 December 2020].

10. Glass-O'Shea, B., (2011). The history and future of genetically modified crops: Franken foods, super weeds, and the developing world. J. Food L. \& Pol'y, 7, p.1.

11. Glover, D., (2007). Monsanto and smallholder farmers: A case study in CSR. Third World Quarterly, 28(4), pp.851-867.

12. Gupta, A., (200)2. Ensuring 'Safe Use 'of Biotechnology: Key Challenges. Economic and Political weekly, pp.2762-2769.

13. Hadari, Y., (1973). The Structure of the Private Multinational Enterprise. Michigan Law Review, 71(4), pp.729-806.

14. Holt-Giménez, E., (2009). From food crisis to food sovereignty: the challenge of social movements. Monthly Review, 61(3), p.142.

15. Kalen, S., (2011). Agriculture, food, and environmental policy. Nat. Resources \& Env't, 26, p.3.

16. Kleinman, D.L. and Kloppenburg, J., (1991), September. Aiming for the discursive high ground: Monsanto and the biotechnology controversy. In Sociological Forum (Vol. 6, No. 3, pp. 427447). Kluwer Academic Publishers-Plenum Publishers.

17. Kobrin, S.J., (2009). Sovereignty@ bay: Globalization, multinational enterprise, and the international political system. The Oxford Handbook of International Business (2 ed.).

18. Kogut, B. and Kulatilaka, N., (1994). Operating flexibility, global manufacturing, and the option value of a multinational network. Management science, 40(1), pp.123-139.

19. Lerche, J., (2007). A global alliance against forced labour? Unfree labour, neo-liberal globalization and the International Labour Organization. Journal of Agrarian Change, 7(4), pp.425-452.

20. Lozano, J.F. and Boni, A., (2002). The impact of the multinational in the development: An ethical challenge. Journal of Business Ethics, 39(1-2), pp.169-178.

21. McClymont, M., (2011). The World According to Monsanto: Pollution, Politics, and Power. An Investigation into One of the World's Most Controversial Companies. MM. Robin (2008). Publisher: Spinifex, Melbourne, Australia. ISBN: 9781876756833. pp 373. Australian Journal of Environmental Education, 27(2), pp.255-255.

22. Moran, T., Graham, E.M. and Blomström, M. eds., (2005). Does foreign direct investment promote development? Columbia University Press

23. Perlmutter, H.V., (1972). The multinational firm and the future. The Annals of the American Academy of Political and Social Science, 403(1), pp.139-152.

24. Pray, C.E., (2001). Public-private sector linkages in research and development: Biotechnology and the seed industry in Brazil, China and India. American Journal of Agricultural Economics, 83(3), pp.742-747.

25. Shah, A., (2002). Corporations and the Environment. Global Issues.

26. Shiva, V., 1991. The violence of the green revolution: third world agriculture, ecology and politics. Zed Books.

27. Solomon, S., (2007). IPCC (2007): Climate change the physical science basis. AGUFM, 2007, pp. U43D-01.

28. Walters, R.S., (1972). International Organizations and the Multinational Corporation: An Overview and Observations. The ANNALS of the American Academy of Political and Social Science, 403(1), pp.127-138.

29. Zepeda, J.F., (2006). Coexistence, genetically modified biotechnologies and biosafety: implications for developing countries. American Journal of Agricultural Economics, 88(5), pp.1200-1208. 